\title{
ECONOMIC FACTORS AND FORECAST OF APPLE PRODUCTION IN DEVELOPMENT BIOENERGY IN POLAND AND ITS USE IN AGRITOURISM
}

\author{
MICHAŁ ROMAN, ${ }^{1}$ KAMIL ROMAN $^{2}$ \\ ${ }^{1}$ Warsaw University of Life Sciences, POLAND \\ e-mail: michal_roman@sggw.pl \\ ${ }^{2}$ Institute of Technology and Life Sciences, POLAND \\ e-mail: k.roman@itp.edu.pl
}

RECEIVED
ACCEPTED
JEL
CLASSIFICATION

KEYWORDS forecasting, economics, rural areas, apple production, bioenergy, agritourism

ABSTRACT The aim of this article is to present the forecast of apples production in Poland in the development of bioenergy in rural areas. The work also drew attention to the use of apples in agricultural and agritourism. Data from the Central Statistical Office (CSO) in Poland were used in 2008-2015 and the forecast was calculated from 2016 to 2030. In addition, information from literature reviews was taken into account. Forecasting methods were calculated in Microsoft Excel.

\section{Introduction}

Biomass is a biodegradable waste material, that has been generated by production processes of agricultural or forestry industry (Dz.U. 2015, poz. 317). Biomass can have the liquid or solid physical state, that impact on calorific value. The agro-food industry is one of the basic sources of biomass supply, which can be easily processed to heating or energy purposes. The specific objectives of this paper were to investigate the potential of apples 
production, which is directly linked with biodegradable postproduccion waste material. That waste resources can covers the action plans of renewable energy usage. Therefore, the balance of development possibilities involves the apple pomace as a source of renewable energy.

\section{Objective, material and pesearch methods}

The present article aims to present the forecast of production in Poland which is directly linked with bioenergy development in rural areas. The research also concerns the usefulness of agriculture and agritourism. Data from the Central Statistical Office in Poland since 2008 to 2015 were used, other data from 2016 to 2030 as a forecast was calculated. The information from literature reviews was also taken into account. During the calculations formula 1, 2 and 3 were used.

$$
Y_{t}=\mathbf{f}\left(t, \varepsilon_{t}\right) \quad \text { for } \quad t=1,2, \ldots, n
$$

or

$$
\mathrm{Y}_{t}=\mathrm{f}\left(t, \mathrm{Y}_{\mathrm{t}-1}, \mathrm{Y}_{\mathrm{t}-2, \ldots, \ldots} \mathrm{Y}_{\mathrm{t}-\mathrm{i},} \varepsilon_{\mathrm{t}}\right) \quad \text { for } \quad t=i+1, i+2, \ldots, n ; \quad i=1, \ldots, p<n
$$

where: $\varepsilon$ is a random component (of random fluctuations).

The forecast of an explanatory variable $\mathrm{Y}$ in period $\mathrm{T}>\mathrm{n}$ is calculated following the formula:

$$
Y_{T}^{*}=f(T) \text { or } Y_{T}^{*}=f\left(T, Y_{T-1}, Y_{T-2, \ldots,} Y_{T-1}\right)
$$

\section{The apple production in Poland in particular years}

The statistical analysis was performed to estimate the existing biomass resources from apple processing. First part of the paper presents the areal of apple production. In the tables below the weight of apple production in the particular years was presented.

According to CSO data, in the year 2012, 71\% of Polish cultivation area were covered by the apple trees. The apple pomace is a waste produced during the extraction of apple juice. The balance of apple production was based on the balancing of demand and resources. The input values includes the annual stocks, production and import of raw materials. The supply includes consumption, industrial consumption, losses and exports. The annual apples production with calculated forecast since year 2008 to 2030, were presented in Table 3. 


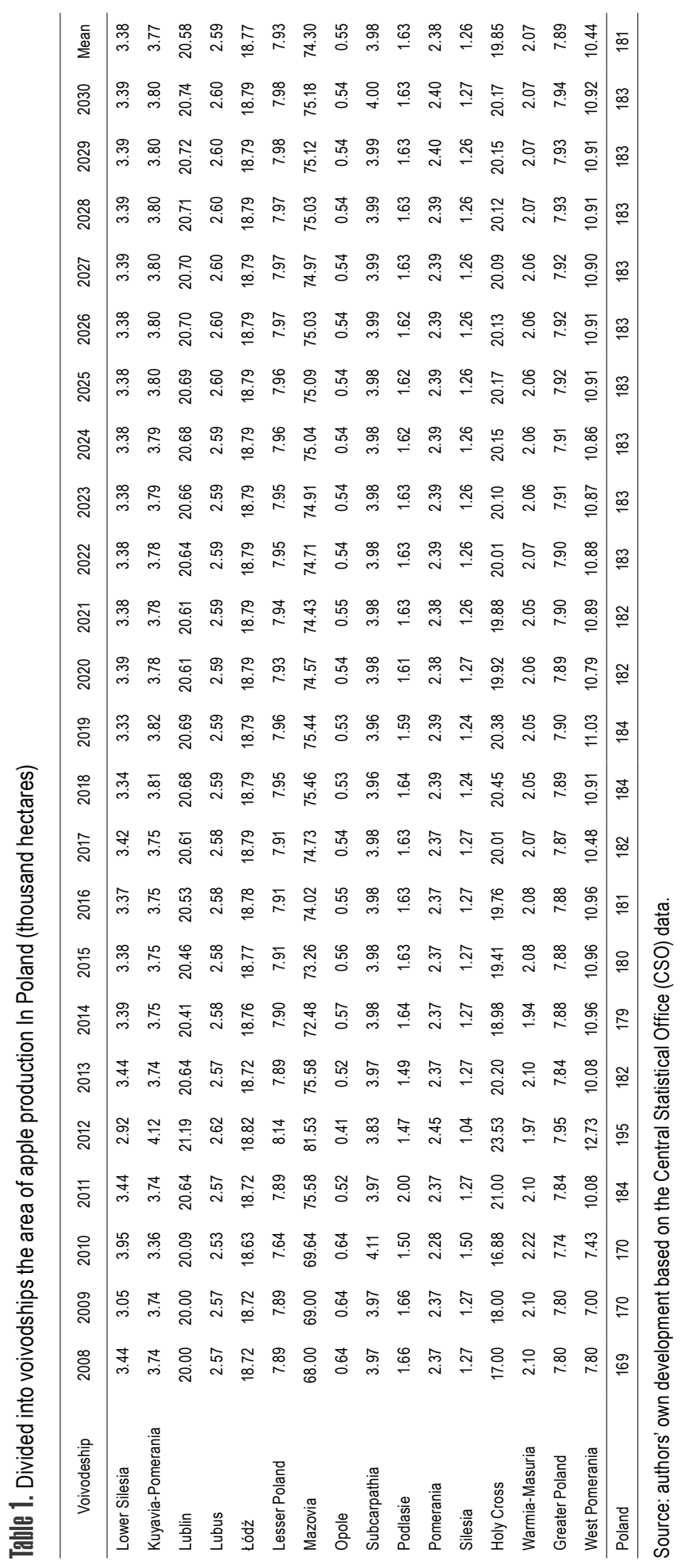




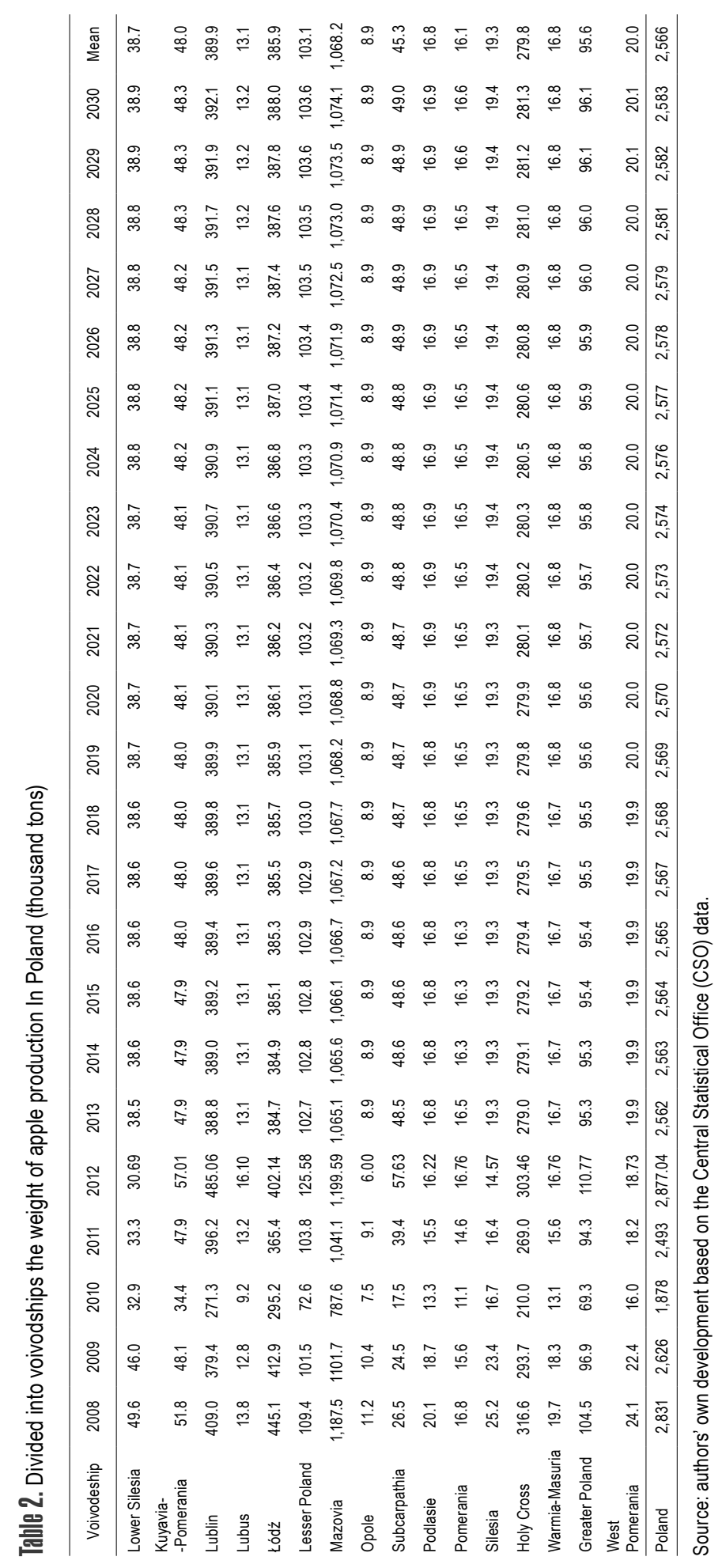


Table 3. The balance of apples production with calculated forecast since year 2008 to 2030 (thousand tons)

\begin{tabular}{|c|c|c|c|c|c|c|c|c|c|c|}
\hline Years & $\begin{array}{l}\text { Initial } \\
\text { stocks }\end{array}$ & Production & Import & $\begin{array}{c}\text { Total } \\
\text { resources }\end{array}$ & Consumption & $\begin{array}{c}\text { Industrial } \\
\text { consumption }\end{array}$ & Losses & Exports & Final stocks & $\begin{array}{c}\text { Apple } \\
\text { pomace }\end{array}$ \\
\hline 2008 & 789.6 & $2,830.9$ & 35.4 & $3,655.9$ & 555 & 800.0 & 182.8 & 410.4 & $1,707.7$ & 341.5 \\
\hline 2009 & $1,707.7$ & $2,626.3$ & 22.2 & $4,356.2$ & 599.4 & 930.0 & 217.8 & 777.1 & $1,831.9$ & 366.4 \\
\hline 2010 & $1,831.9$ & $1,877.9$ & 40.7 & $3,750.5$ & 555 & 845.0 & 187.5 & 724.7 & $1,438.3$ & 287.7 \\
\hline 2011 & $1,438.3$ & $2,493.1$ & 65.3 & $3,996.7$ & 488.4 & 785.0 & 199.8 & 533.6 & $1,989.8$ & 398.0 \\
\hline 2012 & $1,989.8$ & $2,877.3$ & 51.4 & $4,918.5$ & 502.1 & 868.0 & 245.9 & 958.4 & $2,344.1$ & 468.8 \\
\hline 2013 & $2,344.1$ & $2,925.0$ & 35 & $5,304.1$ & 573.6 & 972.0 & 265.2 & $1,250.0$ & $2,243.3$ & 448.7 \\
\hline 2014 & $2,243.3$ & $2,562.7$ & 45 & $4,851.0$ & 548.4 & 973.0 & 242.6 & $1,230.8$ & $1,856.3$ & 371.3 \\
\hline 2015 & $1,856.3$ & $2,564.0$ & 55 & $4,475.3$ & 576.5 & 950.0 & 223.8 & $1,060.8$ & $1,664.2$ & 332.8 \\
\hline 2016 & $1,664.2$ & $2,565.2$ & 58 & $4,287.5$ & 445.4 & 945.0 & 214.4 & $1,090.8$ & $1,591.9$ & 318.4 \\
\hline 2017 & $1,591.9$ & $2,566.7$ & 62 & $4,220.5$ & 520 & 938.0 & 211.0 & 920.8 & $1,630.6$ & 326.1 \\
\hline 2018 & $1,630.6$ & $2,567.9$ & 54 & $4,252.6$ & 543.7 & 880.5 & 212.6 & $1,150.9$ & $1,464.9$ & 293.0 \\
\hline 2019 & $1,464.9$ & $2,569.2$ & 58 & $4,092.1$ & 578.4 & 971.0 & 204.6 & 990.9 & $1,347.2$ & 269.4 \\
\hline 2020 & $1,347.2$ & $2,570.5$ & 72 & $3,989.7$ & 523.4 & 917.9 & 199.5 & $1,010.9$ & $1,338.0$ & 267.6 \\
\hline 2021 & $1,338.0$ & $2,571.7$ & 68 & $3,977.8$ & 621.4 & 909.7 & 198.9 & $1,024.4$ & $1,223.4$ & 244.7 \\
\hline 2022 & $1,223.4$ & $2,573.0$ & 57 & $3,853.4$ & 610.6 & 890.2 & 192.7 & 866.2 & $1,293.7$ & 258.7 \\
\hline 2023 & $1,293.7$ & $2,574.3$ & 66 & $3,934.0$ & 498.7 & 929.4 & 196.7 & $1,208.1$ & $1,101.1$ & 220.2 \\
\hline 2024 & $1,101.1$ & $2,575.6$ & 82 & $3,758.7$ & 542.7 & 923.4 & 187.9 & $1,049.9$ & $1,054.7$ & 210.9 \\
\hline 2025 & $1,054.7$ & $2,576.8$ & 76 & $3,707.6$ & 610.3 & 871.4 & 185.4 & 991.7 & $1,048.7$ & 209.7 \\
\hline 2026 & $1,048.7$ & $2,578.1$ & 70 & $3,696.8$ & 623.8 & 911.1 & 184.8 & 933.6 & $1,043.5$ & 208.7 \\
\hline 2027 & $1,043.5$ & $2,579.4$ & 64 & $3,686.9$ & 643.1 & 926.2 & 184.3 & $1,075.4$ & 857.8 & 171.6 \\
\hline 2028 & 857.8 & $2,580.7$ & 78 & $3,516.5$ & 593.4 & 913.4 & 175.8 & $1,117.3$ & 716.6 & 143.3 \\
\hline 2029 & 716.6 & $2,581.9$ & 80 & $3,378.5$ & 687.2 & 900.3 & 168.9 & $1,059.1$ & 563.0 & 112.6 \\
\hline 2030 & 563.0 & $2,583.2$ & 65 & $3,211.2$ & 560.3 & 933.9 & 160.6 & 900.9 & 655.5 & 131.1 \\
\hline
\end{tabular}

Source: authors' own development based on the Central Statistical Office (CSO) data.

\section{The energy value and physical properties of apple pomace}

The apple pomace are the residues that came from apple pulp pressing process. The residues consist the squeezed seeds, fibers or apple peels. They are widely used in the animal feeds, fruit tea and pectin production or as a supplement to healthy food. Apple pomace are also produced during the wine, juice or apple concentrate production.

In the year 2004, (Kowalczyk, 2004, pp. 21-30) defined the apples rate consumption, calculated as an efficiency of the apple pulp pressing and apple pulp mass according to raw material mass. Indicator specified the consumption of apples per unit of juice concentrate (tonne). The study was conducted in a medium-sized manufacturing plant, fruit and vegetable industry. 35,000 tons of apples were converted. Along with higher summer temperature (July, August, September) the incrases of the apple pressig performance was notice. Assuming that $20 \%$ of the apples pulp responds the one ton of apples, 7,000 tons of apple pomace can be obtained. In the year 2009 (Borycka, 2009, pp. 847-851) during the research, confirmed the usefulness of apple pomace for energy purposes. The gross energetic value from dry matter apple pomace content $17.7 \mathrm{MJ} / \mathrm{kg}$. Currently, because of technical lack, the energetic resources of apple pomace is not used on a wide scale. Selected parameters of dry matter apple pomace was presented in Table 4. 
Table 4. Selected parameters of dry matter apple pomace

\begin{tabular}{lcc}
\hline \multicolumn{1}{c}{ Parameters } & Unit & Value \\
\hline Moisture & $\%$ & $8-10$ \\
Protein & $\%$ & 12 \\
Ash & $\%$ & 4 \\
Fat & $\%$ & 5.7 \\
Crude fiber & $\%$ & 16.8 \\
Gross energetic value & $\mathrm{MJ} / \mathrm{kg}$ & 12,900 \\
Vitamins B1 & $\mathrm{mg} / 100 \mathrm{~g}$ dried & 0.07 \\
Vitamins B2 & $\mathrm{mg} / 100 \mathrm{~g}$ dried & 0.23 \\
Vitamins PP & $\mathrm{mg} / 100 \mathrm{~g}$ dried & 1.50 \\
Vitamins C & $\mathrm{mg} / 100 \mathrm{~g}$ dried & 3.00 \\
\hline
\end{tabular}

Source: http://www.gieldarolna.pl.

\section{The forecasts price for apples and apple pomace as an individual types of biomass}

The price of apple pomace depends on the apples cultivation area. The type of apples are the main dependent of apples price, but not impact on the average apple wholesale price. Price differences are between the sale of dessert and industrial apples. The average price for dessert apples is $1.3 \mathrm{PLN} / \mathrm{kg}$ and for industrial apples $0.50 \mathrm{PLN} / \mathrm{kg}$. The apple pomace in the dry matter form are also available on the same market. Mostly they are intended for feed purposes, that's why their energetic purposes are limited. The apple pomace are the source of many vitamins. Preparing them for feed purposes needs dedicated processing and drying. On the total cost of apple pomace, besides the price of industrial apples also affects the bulk density. Table 5 presents the characteristics of the apples and apple pomace market price in the years 2008-2030.

Table 5. Price comparison of dessert and industrial apples and the dry matter of apple pomace in 2008-2030 (PLN/kg)

\begin{tabular}{cccc}
\hline Years & Dessert apples & Industrial apples & Apple pomace* $^{*}$ \\
\hline 1 & 2 & 3 & 4 \\
2008 & 0.9 & 0.2 & 0.4 \\
2009 & 0.9 & 0.2 & 0.4 \\
2010 & 1.9 & 0.7 & 1.7 \\
2011 & 1.3 & 0.7 & 1.7 \\
2012 & 1.2 & 0.4 & 1.0 \\
2013 & 1.3 & 0.5 & 1.3 \\
2014 & 1.5 & 0.7 & 1.7 \\
2015 & 1.6 & 0.7 & 1.9 \\
2016 & 1.6 & 0.8 & 2.1 \\
2017 & 1.7 & 0.9 & 2.2 \\
2018 & 1.8 & 0.9 & 2.4 \\
2019 & 1.8 & 1.0 & 2.6 \\
2020 & 1.9 & 1.1 & 2.8 \\
2021 & 2.0 & 1.2 & 2.9 \\
2022 & 2.0 & 1.2 & 3.1 \\
2023 & 2.1 & 1.3 & 3.3 \\
\hline
\end{tabular}




\begin{tabular}{cccc}
\hline 1 & 2 & 3 & 4 \\
\hline 2024 & 2.2 & 1.4 & 3.5 \\
2025 & 2.3 & 1.4 & 3.7 \\
2026 & 2.3 & 1.5 & 3.8 \\
2027 & 2.4 & 1.6 & 4.0 \\
2028 & 2.5 & 1.6 & 4.2 \\
2029 & 2.5 & 1.7 & 4.4 \\
2030 & 2.6 & 1.8 & 4.6 \\
\hline
\end{tabular}

*http://www.stadniny.pl/ogloszenia/1389811348.

Source: Data of Horticulture Economics Department IERiGŻ-PIB.

The significant amount of biodegradable waste come from Polish food processing manufacturers. Depends of the biomass form, the residues can be managed on the different ways, for example as an biodegradable fuel. Therefore, biomass for energetic purpose can be obtained from the fruit and vegetable industry, eg apple pomace.

There are 1,363 companies operating in fruit and vegetable processing and 270 companies in the industrial scale. The production of apples is dispersed while the product is supplied by small industrialists. The apple pomace are produced in the food industry during the squeezing, after juice extraction. The squeeze matter can be also a good raw material for cattle feed or further processing, and competitiveness can be developed by the feed businesses.

\section{The cost of producing apples and their seasonality}

The production of apples in the early 1990s was quite profitable. In the 21 st century despite the welfare season, the purchase price does not always coincide with the price of production. In the harvest that count three million tons, the cost of cultivating dessert apples is between $0.8-0.9 \mathrm{PLN} / \mathrm{kg}$ and in the case of industry apples is $0.3-0.35 \mathrm{PLN} / \mathrm{kg}$. Production costs are mostly dependent on yield. The most profitable season for the apples cultivation was the breakthrough of year 2012 and 2013. In those years the welfare was noticed, which did not affect the price of the crop. In other Western European countries not very high harvest were the results. The cultivation of 40 tonnes apples per hectare costs is between 0.70 and $1.00 \mathrm{PLN} / \mathrm{kg}$ and over 60 tons is about $0.60 \mathrm{PLN} / \mathrm{kg}$.

Seasonality has an impact on the buying apples price, eg the price for dessert apples delivered in autumn costs 1.0-1.4 PLN/kg and industrial apples about $0.40-0.45 \mathrm{PLN} / \mathrm{kg}$. The coming years will bring the profitability for producers of apples with a yield over 40 tonnes apples per hectare, where apples characterizes good quality and exportable.

The cost of pressing and drying apple pomace should be added to the unit costs of production. Because the apple pomace are produced as a byproduct of juice production, unit sales of juices can be counted as a profit. At the current price of industrial apples $(0.35 \mathrm{PLN} / \mathrm{kg})$ the unit cost of producing 1 liter of juice does not exceed $4 \mathrm{PLN}$.

\section{Agricultural and agnitourism apples usage}

In Poland, the fruits like apples have very wide use. For example the owners of organic farms provides direct sells of apples at their premises (Roman, 2015, pp. 136-137). In agriculture apple pomace are used in cattle feeds (eg as feed for calves or for further processing). In agritourism apples, plums and cherries are often used in jam production or used in desserts and cakes (eg, custom menu). The owners of agrotourism or agroecotourism in 
Poland are also producers and sellers of cider. Besides, various educational institutions are conducting the programs with apples usage (eg, ecological workshops for primary and post-primary schools). These are mainly educational programs like "From apple to juice", "Laboratory of taste", "Hotel for insects", "Food production", "Agrobusiness for junior high school" or "Ecological programs".

The innovative character of usage the apple symbol can be seen in thematic villages. In Poland, the thematic villages have an influence on the development of a given region, including the integration of the environment in rural areas. In Poland there are thematic villages, eg "Apple village - active village" in Jablonka in the Kuyavia-Pomerania voivodeship, as well as in the village of Stare Jablonki "Apple-flavored village" in Warmia-Masuria voivodship. In these villages are arranged special offers for tourists like: "Appleland Olympics", "Tasting apple delicacies", "Apple talks" (http://www.aktywnawies.pl).

\section{Conclusions}

Basing on the analysis and observations of authors, several conclusions and generalizations were proposed:

- the agro-food industry is one of the main sources of biomass that can easily be converted into heat or power,

- biomass for energy use can be obtained from the fruit and vegetable industry, such as apple pomace,

- there are 1363 companies operating in fruit and vegetable processing and 270 companies in the industrial scale. The production of apples is dispersed while the product is supplied by small industrialists. Apple pomace are produced in the food industry, after squeezing juice, that can be a good raw material for cattle feed or further processing,

- apple pomace can be widely used in agricultural and agro-tourism, for exemple in cattle feed, calf feed, for further processing, to tourists meals in agritourism or in cider production.

\section{References}

Borycka, B. (2009). Walory ekologiczne spalania biomasy z odpadów owocowo-warzywnych. Energetyka, 12, 847-851.

Data of Horticulture Economics Department IERiGż-PIB.

Development based on the Central Statistical Office (CSO) data.

Dz.U. 2015, poz. 317 - Dziennik Ustaw Rzeczypospolitej Polskiej, poz. 317. Rozporządzenie Prezesa Rady Ministrów z dnia 2 marca $2015 \mathrm{r}$. zmieniające rozporządzenie w sprawie określenia wzorów formularzy sprawozdawczych, objaśnień co do sposobu ich wypełniania oraz wzorów kwestionariuszy i ankiet statystycznych stosowanych w badaniach statystycznych ustalonych w programie badań statystycznych statystyki publicznej na rok 2014, 5 .

http://www.aktywnawies.pl/wioska-jabloni,wt21,11.html.

http://www.gieldarolna.pl.

http://www.stadniny.pl/ogloszenia/138981134.

Kowalczyk, R. (2004). Wydajność tłoczenia i wskaźnik zużycia jabłek w procesie wytwarzania zagęszczonego soku jabłkowego. Problemy Inżynierii Rolniczej, 2, 21-30.

Roman, M. (2015). Agritourism farms owners' competence in running their economic activities. Polish Journal of Management Studies, $1(11), 136-137$.

Cite this article aS: Roman, M., Roman, K. (2018). Economic factors and forecast of apple production in development bioenergy in Poland and its use in agritourism. European Journal of Service Management, 3 (27/1), 233-240. DOI: 10.18276/ejsm.2018.27/1-29. 